\title{
Stressors and Counselling Needs of Undergraduate Nursing Students in Osogbo, Nigeria
}

\author{
Article by Lilly-West, R.B \\ Medical Department, Shell Petroleum Development, Port Harcourt, Nigeria \\ E-mail: buloala2002@yahoo.com
}

\begin{abstract}
Background: Education is important in the development of any profession. It is the process of transferring knowledge from a generation of professionals to another. Stress can be beneficial in the education of a student, motivating them to reach their full potential. However, nursing education has its peculiar attendant stress that can be harmful when excessive. Majority of nursing students around the world have reported a level of stress in their academic pursuit. Objective: The study was carried out to determine the stress level of students in the various levels of the nursing education, to examine the pattern of stress amidst the students according to their sociodemographic, and to determine the relationship between the various coping mechanisms adopted and the overall stress score through a questionnaire- based study in a government school of nursing in Osun state, Nigeria. Method: A descriptive crosssectional study was carried out at the Osun state school of nursing, Asubiaro, Osogbo, Osun state. A sample of 120 students was drawn from all the classes of the school using a multistage sampling method of proportional allocation. To achieve the objective of the study, a questionnaire was designed that contained three sections; A. Sociodemographic data, B. The perceived stress scale (PSS) and C. The brief coping orientation for problem experiences (COPE). Data were entered and analysed using the statistical package for social sciences (SPSS) version 20.0. Results: The mean age of the respondents was $22.11 \pm 4.14$ years with the median and range being 21.00 and 30.00 years respectively. About $78 \%$ of the respondents are females and $70 \%$ are Christians. Using the PSS, $48.3 \%$ of the respondents sometimes become upset because of something that happened unexpectedly, 17.5\% becomes upset fairly often, $12.5 \%$ almost never becomes upset among the others. Equal number of respondents (5.8\%) never or almost never felt nervous or stressed in the last month, others sometimes (44.2\%), fairly often (19.2\%) and very often (25.0\%) feel nervous or stressed. Other responses about the PSS are presented in table 2. There is a significant difference between the stress score of the respondents in between the sexes (16.70 vs 19.17; $p=0.045)$. Also, the proportion of the females that are stressed is significantly more than the proportion of the males $(66.7 \%$ vs $87.1 \%$; $p=0.018$ ). The odds of respondents who practice behavioural disengagement to be highly stressed is 0.262 (95\% CI, 0.117 - 1.483) times that of respondents who practice other coping mechanisms. Conclusion: The level of stress in the population studied is relatively low when compared with the results from other studies both locally and internationally. The various stressors identified are basically as a result of lack of control over academic events, nervousness, inability to handle personal problems, irritations, and anger. The nursing education authority should look into these stressors with the view to find ways of mitigating them, thereby providing an optimum learning environment for the students. Some of the students already practice both active and avoidant coping techniques.
\end{abstract}

Keywords: stressors, counselling, perceived stress scale (PSS), coping orientation for problem experiences (COPE).

\section{Introduction}

Stress in nursing education is beginning to get the attention of nurse educators and nurse researchers in the recent years because its effects on learning, persistence and the overall students' satisfaction and wellbeing have been recognized (DelPrato et al, 2011). 
Nursing education exposes students to a greater level of stress when compared to students undergoing other education (Gibbons et al, 2007). Among other potential sources of stress, the peculiarity of the educational standard is a risk factor for higher stress levels. These peculiarities range from insecurity about clinical experience to excessive assignments and interpersonal conflicts with other nurses (Nancy, 2011). As a result of these experiences, the student nurses undergo some long term negative changes in their physical and mental well-being, often becoming irritable, lacking concentration, academically poor, emotionally unstable and showing truancy (Chang et al, 2005, Gibbons, 2010; Al-Kandari \& Vidal, 2007).

Absenteeism in the students is critical because it can lead to a decline in the number of students graduating from the nursing schools and a corresponding shortage in the number of professional nurses available to serve the population (Deary et al, 2003; Watson et al, 2008). This is also important because these "drop-outs" might end up establishing quack health centres in some remote locations, claiming to the people that they are graduates. A study by Leodoro, 2013 has shown that the stresses encountered by nursing students are severe enough to cause some mental health problems such as depression and anxiety (Leodoro, 2013).

Going through a rather stressful education, numerous nursing students have utilized several coping strategies in times past, these includes self- distraction, active coping, denial, substance use and religion among others (Seyedfatemi et al, 2007; Sheu et al, 2002).

\section{Research problem}

Nursing education cannot be overlooked in the quest to ensure that the nurses in the health sector are professionals who are up to the task of quality healthcare delivery. Generally, this part of the world has inadequate data on the various stressors of the students and how stressed they are in their nursing education, there is little or no information how these students have been coping with the various stressors making interventions difficult and the learning process harder.

The earlier reports were made using scales that were not standardized and universal. There is a need to assess these subjects using a universal scale so that there can be basis for proper comparism between the local data and data from other nursing institution in the world.

\section{Significance of the study}

Understanding the various stressors that the students encounter in their nursing education will help the nurse educators and the nursing council to better create a supportive environment for the students, and reduce the likelihood and incidence of the negative events associated with excessive stress.

This study will provide information concerning the stress level of the nursing students in their nursing education. It will also provide information about the various ways in which they have been trying to cope with their stresses. This study could help the nursing education authorities in designing a better learning environment which reduces the stress that students will go through. Knowing the various coping mechanism already employed can also direct the relevant authorities on where to focus more while trying to reduce the stress of the students.

\section{Objectives of the study}

The objectives of the study are: to determine the stress level of the students in the various levels of the nursing education, to examine the pattern of stress amidst the students according to their sociodemographic, and to determine the relationship between the various coping mechanisms adopted and the overall stress score.

\section{Research questions}

What is the stress level of the students in the various levels of the nursing education what is the stress pattern amidst the students?

What is the relationship between the various coping mechanisms and the overall stress scores? 
What coping factors determine a higher overall stress level among the students?

\section{Scope of the study}

The study assessed the stress levels and associated factors among first year, second year and third year students of the school of nursing Osogbo, Osun State, Nigeria. The questionnaire was self-administered and the nurses that took part ranged from both freshers and finalists all within the undergraduate nursing education.

\section{Literature review}

\section{Introduction}

This section presents the relevant literature taken from primary and secondary sources of either research or conceptual literature.

Stress and stressors-- In 1984, stress was defined as "a particular relationship between the person and the environment that is appraised by the person as taxing or exceeding his or her resources and endangering his or her wellbeing" (Lazarus \& Folkman, 1984). Stress in itself is not always negative, and in some circumstances, it can be positive, motivating students and enhancing their performance. However, in conditions of excessive stress there are negative impacts on the students' physical and mental health.

Stress is a dynamic interaction between an individual and his environment. The environment of an individual plays a prominent role in their psychosocial life, and in extension their physical and mental well-being (Kohler et al, 2006; Pulido-Martos et al, 2011; Chang et al, 2005). As a result of the caring nature of the nursing profession, a lot of professional nurses undergo a lot of work-related stress, the nursing students are exposed to the same stressors the professional nurses are exposed to and they are also exposed to the education-related stress of a student (Lim et al, 2010; Pryjmachuk \& Richards, 2007).

Even among nursing students, stress levels vary depending on the educational levels of the students and the different nursing programmes (Lindop, 2000; Burnard et al, 2008). The various stressors encountered by the nursing students can be broadly classified into four groups (Pryjmachuk \& Richards, 2007; Deary et al, 2003; Brown et al, 2000; Nancy, 2011);

Academic stress: These are stress that the students go through as a result of direct academic pressures on them. These includes workload, examinations, lecturing methods, assignment submission, excessive homework, assessment deadlines, unclear assignments, uncomfortable classrooms and the pressure resulting from the fear of elimination from the training.

Clinical practice related stress: This kind of stress arises from the exposure of the nursing students to clinical training. These include lack of competence, shifting, insecurity about clinical competence, interpersonal relations with patients (especially the dead and dying), supervision and assessment among others.

Relational stress: These are the stress the students experience as a result of their relationships in the nursing education. These include interacting with patients, interpersonal conflicts with other nurses, and relations with faculty members.

Intrapersonal stress: These stresses are particularly attributable to the personal state of the students themselves. These include gender, age, lack of motivation, poor social life coupled with the transition from the family background to the school environment, family structure, financial burdens, time pressure and job roles.

In 2010, Liu et al published a report that detailed the transition of nursing education from the conventional hospital based three-year programme to the current tertiary education based baccalaureate degree program. The reform also includes the shift in clinical practice from supervision and assessment of nursing students to a cooperative work between the university nursing faculty and clinical nurses (Liu et al, 2010). This shift in the structure of nursing education has also brought attendant increment in the stress levels of the students.

In a 2011 study in India, it was discovered that change in environment, inadequate telephone facilities, change in eating pattern, engagement/marriage induced stress in $100 \%$ of the students, while the least stressors are missing too many classes (16\%), inadequate water supply 
DOI: $10.21522 /$ TIJNR.2015.03.02.Art005

ISSN: $2520-3126$

(19\%), conflict with roommates (30\%), inadequate electricity supply (32\%), change in religious beliefs (46\%), lack of close and intimate friends (49\%) among others (Sharma \& Kaur, 2011). They concluded that stress cannot be eliminated but it can be reduced.

Coping strategies/mechanisms: Coping strategies can be defined as the "specific efforts, both behavioural and psychological, that people employ to master, tolerate, reduce, or minimize stressful events" (Ajibade et al, 2016). MacArthur (2014) categorized coping strategies according to figure 1 .

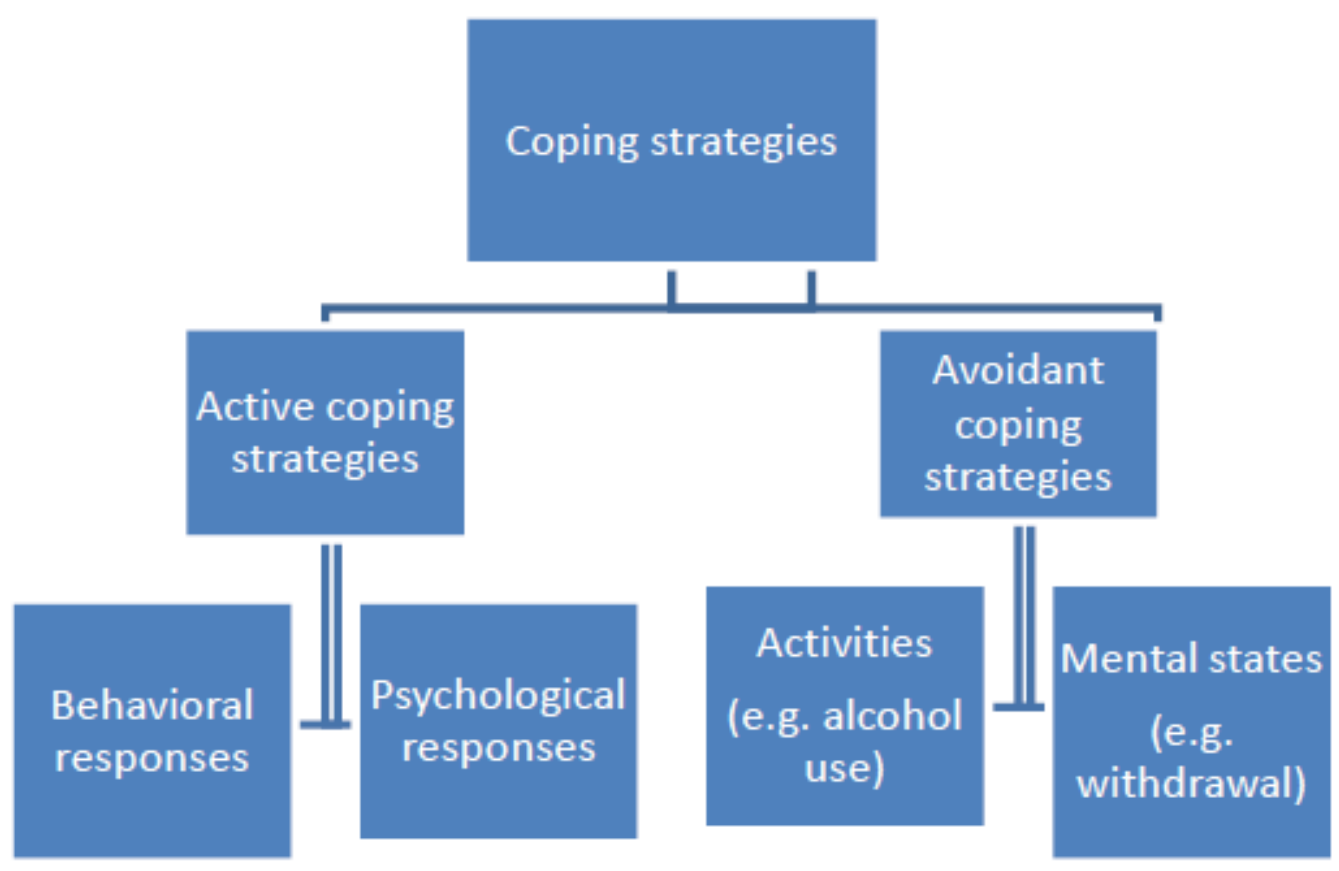

Figure 1. Classification of coping strategies according to MacArthur (2014)

The stress level of the students can be modified by the adoption of various coping strategies. When the coping strategy employed by the student is effective, there is a significant improvement in their educational results. As a result of relieved stress (Khater et al, 2014). The various coping mechanisms employed by the students are largely dependent on the educational level of the student and also the type of stress the student is going through. However, the overall aim of the students is to survive, grow, and maintain their individual integrity (Nancy, 2011).

Stress-coping strategies in nursing education require creating a change in the educational environment and empowering the students to be able to cope better with their encountered stress (DelPrato et al, 2011).

Mentorship together with guidance and counselling can be a very useful strategy in the bid to reduce anxiety in the students when they go through clinical attachment (Aston \& Molassiotis, 2011; Frankel, 2009; Papastsvrous et al, 2010). Senior nursing students can help the juniors nursing to understand some scenarios better (Aston \& Molassiotis, 2011). Members of staff can personally mentor some of these students; guiding them and helping them acclimatize to the new learning environment. Mentorship can graduate into role-modelling and these nursing students can have an already made professional to look up to, reducing the tendencies of drop out and increasing their motivation and in extension academic performance (Papp et al, 2003). The students also learn leadership skills from their mentors apart from academic direction.

Adopting a caring environment can also go a long way in helping the students to cope with excessive stress. A 2005 study implied that creating a caring environment defined as an environment where the lecturer know and responds to "the feelings of stress and anxiety that are experienced by the students" shows value, respect and support in between the faculty and 
the students, further promoting learning in a manner that is less stressful. (Hughes, 1992; Bankert \& Kozel, 2005)

A 2016 multicentre study in south-western Nigeria identified four major coping mechanisms used by undergraduate nursing students. They show that most of the students utilize "problem solving" and "staying optimistic" the most as coping mechanisms in their academic pursuit (Ajibade et al, 2016). They report that the students do not especially use "avoidance and transference". Avoidance as a coping strategy has been associated with increased stress on the long run and is a sign of a possible underlying psychological problem (Sheu et al, 2002; Boyes, 2013).

\section{Methodology}

\section{Study location}

The study was carried out in the school of nursing Osogbo. The school was established by the Osun state ministry of health to cater for the need for nurses training in the state. Osogbo is the capital of Osun state in South western, Nigeria. The school is located inside the compound of the state hospital, Asubiaro.

\section{Type of study}

This study was a cross-sectional study of stress levels of nursing students in the school of nursing Osogbo. Data was collected from a representative subset of nursing students studying in the school.

\section{Sample Size/population}

The study population consisted first year, second year and third year students of the school, which were estimated to be four hundred (400) in number.

\section{Sample and sampling strategy}

A sample of one hundred and twenty (120) students was selected by convenience sampling through a multi-stage sampling of proportional allocation by taking $40 \%$ of the first year students, $20 \%$ of the second year students and $40 \%$ of the third year students. Sampling in a class was through simple random sampling using the ballot system.

\section{Selection criteria for the subjects}

\section{Inclusion criteria}

i. Nursing students in the school of nursing, Osun State

ii. Nursing students older than 18 years.

iii. Students that gave informed consent to be enrolled.

\section{Exclusion criteria}

i. Those who declined consent

\section{Materials}

A questionnaire was used to obtain the various information. It was pre-tested before the study. The questionnaire had three sections; section A requested information about sociodemographic data like age, gender, educational level, religion etc. section B contained the perceived stress scale (PSS), this is a 10-item scale designed to gather examine the stress level of the students. Section $\mathrm{C}$ contained the brief coping orientation for problem experiences (COPE) scale

The questionnaire (Appendix A) consists of three sections in two pages: section A, section $\mathrm{B}$ and section C. Section A contained sociodemographic data like age, sex, educational level, religion etc. Section B contained the perceived stress scale (PSS), a 10-item scale with responses in a liekart scale ranging from Never to Almost Never to Sometimes to Fairly Often to Very Often. Section $\mathrm{C}$ contained the brief coping orientation for problem experiences 
DOI: $10.21522 /$ TIJNR.2015.03.02.Art005

ISSN: $2520-3126$

(COPE), a 28-item tool developed to evaluate the coping mechanisms by students. It has responses on a liekart scale ranging from "I haven't been doing this at all" to "I've been doing this a little bit" to "I've been doing this a medium amount" to "I've been doing this a lot".

\section{Subject assessment}

Informed consent obtained from all the subjects participating in the study. They were then assessed using the study questionnaire.

\section{Statistical analysis}

The data was analysed using Statistical Package for the Social Sciences (SPSS Inc, Chicago, IL version 20.0) software. Categorical variables were described using frequencies and percentages. Also, continuous variables were described using the measures of central tendency (mean, median) and measures of dispersion (range, standard deviation) as appropriate. Statistical significance of differences between means was determined using student's T-test and analysis of variance (ANOVA) where appropriate (Table 3). Significant association of individual coping mechanisms with high stress level among the respondents was tested using Pearson's Coefficient of Correlation for quantitative variables. Regression analysis made done using cumulative odds ordinal logistic regression with proportional odds. Statistical significance was considered at $\mathrm{P}<0.05$.

\section{Ethical clearance}

Ethical clearance was obtained from the Ethics and Research Committee of the (Nursing dept.) Ministry of health, Osogbo, Osun State, Nigeria.

\section{Results}

This section presents the results of the study based on the sequence by which the research questions were raised. The profile of the respondents is presented first followed by the results and discussion.

\section{Respondent's profile (age, gender and religion)}

The mean age of the respondents was $22.11 \pm 4.14$ years with the median and range being 21.00 and 30.00 years respectively as shown in table 1 . Majority $(71.7 \%)$ of the respondents were also in the $18-22$ years age group, others are $23-27$ years $(19.2 \%), 28-32(6.7 \%)$ and $>32(2.5 \%)$. Ninety three $(77.5 \%)$ were females. Religious distribution showed that Christianity accounts for $70.0 \%$ of the religion followed by Islam (30.0\%).

\section{Respondent's profile (educational level, ethnicity and accommodation type)}

Equal proportions $(40.0 \%)$ of the respondents were in their first year and the third years of study while the remaining $20.0 \%$ were in their second year of study. Almost all (92.5\%) of them are Yoruba by ethnicity, others are Igbo (6.7\%) and Hausa (0.8\%). The dominant accommodation type was "school hostel" $-80.0 \%$.

\section{Respondent's profile (average monthly income and family type)}

Majority (81.7\%) of the respondents have less than 20,000 naira as their average monthly income and only one person $(0.8 \%$ ) earned more than 100,000 naira per month, others are inbetween. Also, eighty nine $(74.2 \%)$ are from a monogamous family setting. 
Table 1. Sociodemographic characteristics of the respondents.

\begin{tabular}{|c|c|c|c|}
\hline \multirow{2}{*}{\multicolumn{2}{|c|}{ Variable }} & \multicolumn{2}{|l|}{$\mathbf{N}=120$} \\
\hline & & \multirow{2}{*}{ Frequency } & \multirow[t]{2}{*}{ Percentage } \\
\hline Age (Years) & & & \\
\hline & $18-22$ & 86 & 71.7 \\
\hline & $23-27$ & 23 & 19.2 \\
\hline & $28-32$ & 8 & 6.7 \\
\hline & $>32$ & 3 & 2.5 \\
\hline & Mean \pm SD & \multicolumn{2}{|l|}{$22.11 \pm 4.14$} \\
\hline & $\begin{array}{l}\text { Median } \\
\text { (Range) }\end{array}$ & \multicolumn{2}{|l|}{$21.0(30.0)$} \\
\hline \multicolumn{4}{|l|}{ Gender } \\
\hline & Male & 27 & 22.5 \\
\hline & Female & 93 & 77.5 \\
\hline \multirow{4}{*}{ Religion } & & & \\
\hline & Christianity & 84 & 70.0 \\
\hline & Islam & 36 & 30.0 \\
\hline & Traditional & 0 & 0.0 \\
\hline \multirow{4}{*}{$\begin{array}{l}\text { Educational } \\
\text { Level }\end{array}$} & & & \\
\hline & First year & 48 & 40 \\
\hline & Second year & 24 & 20 \\
\hline & Third year & 48 & 40 \\
\hline \multirow[t]{4}{*}{ Ethnicity } & & & \\
\hline & Yoruba & 111 & 92.5 \\
\hline & Igbo & 8 & 6.7 \\
\hline & Hausa & 1 & 0.8 \\
\hline \multirow{3}{*}{$\begin{array}{l}\text { Accommodation } \\
\text { type }\end{array}$} & & & \\
\hline & $\begin{array}{l}\text { School } \\
\text { Hostel }\end{array}$ & 96 & 80.0 \\
\hline & Off Campus & 24 & 20.0 \\
\hline \multirow{5}{*}{$\begin{array}{l}\text { Average } \\
\text { Monthly Income }\end{array}$} & & & \\
\hline & $<20,000$ & 98 & 81.7 \\
\hline & $20-50,000$ & 16 & 13.3 \\
\hline & $\begin{array}{l}50- \\
100,000\end{array}$ & 5 & 4.2 \\
\hline & $>100,000$ & 1 & 0.8 \\
\hline \multirow[t]{3}{*}{ Family Type } & & & \\
\hline & $\begin{array}{l}\text { Monogamou } \\
\mathrm{s}\end{array}$ & 89 & 74.2 \\
\hline & Polygamous & 31 & 25.8 \\
\hline
\end{tabular}

$\mathrm{SD}=$ standard deviation

\section{Stressors among the respondents}

Using the PSS, $48.3 \%$ of the respondents sometimes become upset because of something that happened unexpectedly, $17.5 \%$ becomes upset fairly often, $12.5 \%$ almost never becomes upset among the others. Equal number of respondents (5.8\%) never or almost never felt nervous or stressed in the last month, others sometimes (44.2\%), fairly often $(19.2 \%)$ and very often (25.0\%) feel nervous or stressed. Other responses about the PSS are presented in table 2. 
Table 2. The response of the respondents to the perceived stress scale

\begin{tabular}{|c|c|c|c|}
\hline & Question statement & $\mathbf{N}$ & $\%$ \\
\hline 1 & $\begin{array}{l}\text { In the last month, how often have you been upset } \\
\text { because of something that happened unexpectedly? } \\
\text { Never } \\
\text { Almost Never } \\
\text { Sometimes } \\
\text { Fairly Often } \\
\text { Very Often }\end{array}$ & $\begin{array}{l}12 \\
15 \\
58 \\
21 \\
14\end{array}$ & $\begin{array}{l}10.0 \\
12.5 \\
48.3 \\
17.5 \\
11.7\end{array}$ \\
\hline 2 & $\begin{array}{l}\text { In the last month, how often have you felt that you } \\
\text { were unable to control the important things in your } \\
\text { life? } \\
\text { Never } \\
\text { Almost Never } \\
\text { Sometimes } \\
\text { Fairly Often } \\
\text { Very Often }\end{array}$ & $\begin{array}{l}26 \\
18 \\
36 \\
23 \\
17\end{array}$ & $\begin{array}{l}21.7 \\
15.0 \\
30.0 \\
19.2 \\
14.2\end{array}$ \\
\hline 3 & $\begin{array}{l}\text { In the last month, how often have you felt nervous } \\
\text { and "stressed"? } \\
\text { Never } \\
\text { Almost Never } \\
\text { Sometimes } \\
\text { Fairly Often } \\
\text { Very Often }\end{array}$ & $\begin{array}{l}7 \\
7 \\
53 \\
23 \\
30\end{array}$ & $\begin{array}{l}5.8 \\
5.8 \\
44.2 \\
19.2 \\
25.0\end{array}$ \\
\hline 4 & $\begin{array}{l}\text { In the last month, how often have you felt confident } \\
\text { about your ability to handle your personal } \\
\text { problems? } \\
\text { Never } \\
\text { Almost Never } \\
\text { Sometimes } \\
\text { Fairly Often } \\
\text { Very Often }\end{array}$ & $\begin{array}{l}9 \\
17 \\
25 \\
32 \\
37\end{array}$ & $\begin{array}{l}7.5 \\
14.2 \\
20.8 \\
26.7 \\
30.8\end{array}$ \\
\hline 5 & $\begin{array}{l}\text { In the last month, how often have you felt that } \\
\text { things were going your way? } \\
\text { Never } \\
\text { Almost Never } \\
\text { Sometimes } \\
\text { Fairly Often } \\
\text { Very Often }\end{array}$ & $\begin{array}{l}9 \\
17 \\
33 \\
34 \\
27\end{array}$ & $\begin{array}{l}7.5 \\
14.2 \\
27.5 \\
28.3 \\
22.5\end{array}$ \\
\hline 6 & $\begin{array}{l}\text { In the last month, how often have you found that } \\
\text { you could not cope with all the things that you had } \\
\text { to do? } \\
\text { Never } \\
\text { Almost Never } \\
\text { Sometimes } \\
\text { Fairly Often } \\
\text { Very Often }\end{array}$ & $\begin{array}{l}20 \\
32 \\
33 \\
25 \\
10\end{array}$ & $\begin{array}{l}16.7 \\
26.7 \\
27.5 \\
20.8 \\
8.3\end{array}$ \\
\hline
\end{tabular}




\begin{tabular}{|c|c|c|c|}
\hline 7 & $\begin{array}{l}\text { In the last month, how often have you been able to } \\
\text { control irritations in your life? } \\
\text { Never } \\
\text { Almost Never } \\
\text { Sometimes } \\
\text { Fairly Often } \\
\text { Very Often }\end{array}$ & $\begin{array}{l}9 \\
15 \\
43 \\
36 \\
17\end{array}$ & $\begin{array}{l}7.5 \\
12.5 \\
35.8 \\
30.0 \\
14.2\end{array}$ \\
\hline & $\begin{array}{l}\text { In the last month, how often have you felt that you } \\
\text { were on top of things? } \\
\text { Never } \\
\text { Almost Never } \\
\text { Sometimes } \\
\text { Fairly Often } \\
\text { Very Often }\end{array}$ & $\begin{array}{l}8 \\
18 \\
41 \\
34 \\
19\end{array}$ & $\begin{array}{l}6.7 \\
15.0 \\
34.2 \\
28.3 \\
15.8\end{array}$ \\
\hline 9 & $\begin{array}{l}\text { In the last month, how often have you been angered } \\
\text { because of things that were outside of your control? } \\
\text { Never } \\
\text { Almost Never } \\
\text { Sometimes } \\
\text { Fairly Often } \\
\text { Very Often }\end{array}$ & $\begin{array}{l}13 \\
23 \\
43 \\
25 \\
16\end{array}$ & $\begin{array}{l}10.8 \\
19.2 \\
35.8 \\
20.8 \\
13.3\end{array}$ \\
\hline 10 & $\begin{array}{l}\text { In the last month, how often have you felt } \\
\text { difficulties were piling up so high that you could not } \\
\text { overcome them? } \\
\text { Never } \\
\text { Almost Never } \\
\text { Sometimes } \\
\text { Fairly Often } \\
\text { Very Often }\end{array}$ & $\begin{array}{l}17 \\
24 \\
41 \\
25 \\
13\end{array}$ & $\begin{array}{l}14.2 \\
20.0 \\
34.2 \\
20.8 \\
10.8\end{array}$ \\
\hline
\end{tabular}

$\mathrm{n}=$ frequency, $\%=$ percentage

Table 3 shows the relationship between these stressors and the sociodemographic characteristics of the respondents. There is a significant difference between the stress score of the respondents in between the sexes $(16.70$ vs $19.17 ; p=0.045)$. Also the proportion of the females that are stressed is significantly more than the proportion of the males $(66.7 \%$ vs $87.1 \%$; $p=0.018$ ). 
DOI: $10.21522 /$ TIJNR.2015.03.02.Art005

ISSN: $2520-3126$

Table 3. Relationship between the sociodemographic characteristics of the respondents and the stress level

\begin{tabular}{|c|c|c|c|c|c|c|}
\hline \multirow{2}{*}{\multicolumn{2}{|c|}{ Variable }} & \multicolumn{2}{|c|}{ Stress Score } & \multicolumn{3}{|c|}{ Abnormal stress level } \\
\hline & & & & & & \\
\hline \multirow{4}{*}{ Gender } & & & \multirow{4}{*}{$\begin{array}{l}0.045 \\
*\end{array}$} & & & \multirow{4}{*}{$\begin{array}{l}6.049(0.018 \\
*)\end{array}$} \\
\hline & & & & & & \\
\hline & Male & $\begin{array}{l}16.70 \pm 6.3 \\
6\end{array}$ & & 18 & 66.7 & \\
\hline & Female & $\begin{array}{l}19.17 \pm 5.3 \\
2\end{array}$ & & 81 & 87.1 & \\
\hline \multirow{4}{*}{$\begin{array}{l}\text { Educational } \\
\text { Level }\end{array}$} & & & \multirow[t]{4}{*}{0.191} & & & \multirow[t]{4}{*}{$0.087(0.958)$} \\
\hline & First Year & $\begin{array}{l}18.46 \pm 5.5 \\
7\end{array}$ & & 39 & 81.2 & \\
\hline & $\begin{array}{l}\text { Second } \\
\text { Year }\end{array}$ & $\begin{array}{l}20.42 \pm 6.8 \\
6\end{array}$ & & 20 & 83.3 & \\
\hline & Third Year & $\begin{array}{l}17.88 \pm 4.9 \\
1\end{array}$ & & 40 & 83.3 & \\
\hline \multirow{3}{*}{$\begin{array}{l}\text { Accommodati } \\
\text { on type }\end{array}$} & & & \multirow[t]{3}{*}{0.380} & & & \multirow[t]{3}{*}{$2.828(0.087)$} \\
\hline & $\begin{array}{l}\text { School } \\
\text { Hostel }\end{array}$ & $\begin{array}{l}18.84 \pm 5.7 \\
1\end{array}$ & & 82 & 85.4 & \\
\hline & Off Campus & $\begin{array}{l}17.71 \pm 6.3 \\
4\end{array}$ & & 17 & 70.8 & \\
\hline \multirow{5}{*}{$\begin{array}{l}\text { Average } \\
\text { Monthly } \\
\text { Income }\end{array}$} & & & \multirow[t]{5}{*}{0.096} & & & \multirow[t]{5}{*}{ 7.532(0.057) } \\
\hline & $<20,000$ & $\begin{array}{l}18.83 \pm 5.5 \\
7\end{array}$ & & 84 & 85.7 & \\
\hline & $20-50,000$ & $\begin{array}{l}17.06 \pm 4.0 \\
4\end{array}$ & & 11 & 68.8 & \\
\hline & $\begin{array}{l}50- \\
100,000\end{array}$ & $\begin{array}{l}21.60 \pm 9.1 \\
0\end{array}$ & & 4 & 80.0 & \\
\hline & $>100,000$ & 8.00 & & 0 & 0.0 & \\
\hline \multirow[t]{3}{*}{ Family Type } & & & \multirow[t]{3}{*}{0.662} & & & \multirow[t]{3}{*}{$0.612(0.314)$} \\
\hline & $\begin{array}{l}\text { Monogamo } \\
\text { us }\end{array}$ & $\begin{array}{l}18.48 \pm 5.9 \\
1\end{array}$ & & 72 & 80.9 & \\
\hline & Polygamous & $\begin{array}{l}19.00 \pm 4.8 \\
2\end{array}$ & & 27 & 87.1 & \\
\hline
\end{tabular}

*=significant, $S D=$ standard deviation

\section{Predictors of high stress level among the respondents}

There was a significant positive correlation between the stress level of the respondents and the following coping mechanisms: Denial $(r=0.152, p=0.048)$, Behavioural disengagement $(r=0.212, p=0.010)$, Self-blame $(r=0.241, p=0.004)$. While there was a significant negative correlation between the stress level of the respondents and the following coping mechanisms: Use of emotional support $(r=-0.172, p=0.030)$, Use of instrumental support $(r=-0.192$, $p=0.018)$, Acceptance $(r=-0.153, p=0.047)$. Others are as shown in table 4 . 
Table 4. Correlation between the individual coping mechanism and high stress level among the respondents

\begin{tabular}{|l|l|l|l|}
\hline Question & N & $\mathbf{R}$ & $\begin{array}{l}\boldsymbol{p}- \\
\text { value }\end{array}$ \\
\hline Self-distraction & 120 & 0.063 & 0.247 \\
\hline Active coping & 120 & -0.110 & 0.115 \\
\hline Denial & 120 & 0.152 & $0.048^{*}$ \\
\hline Substance use & 120 & 0.098 & 0.144 \\
\hline Use of emotional support & 120 & -0.172 & $0.030^{*}$ \\
\hline Use of instrumental support & 120 & -0.192 & $0.018^{*}$ \\
\hline Behavioural disengagement & 120 & 0.212 & $0.010^{*}$ \\
\hline Venting & 120 & -0.051 & 0.291 \\
\hline Positive reframing & 120 & -0.080 & 0.194 \\
\hline Planning & 120 & -0.067 & 0.235 \\
\hline Humour & 120 & -0.064 & 0.243 \\
\hline Acceptance & 120 & -0.153 & $0.047^{*}$ \\
\hline Religion & 120 & -0.107 & 0.122 \\
\hline Self-blame & 120 & 0.241 & $0.004^{*}$ \\
\hline
\end{tabular}

On multiple regression analysis, the odds of respondents who practice behavioural disengagement to be highly stressed is $0.262(95 \% \mathrm{CI}, 0.117-1.483)$ times that of respondents who practice other coping mechanisms, a statistically significant effect, $p=0.022$. (Table 5).

Table 5. Regression analysis of the predictors for a high overall stress score amidst the respondents

\begin{tabular}{|c|c|c|c|c|c|c|}
\hline \multirow[t]{2}{*}{ Variable } & \multirow[t]{2}{*}{ df } & \multirow[t]{2}{*}{$\mathbf{t}$} & \multirow{2}{*}{$\begin{array}{l}\text { Odds } \\
\text { Ratio }\end{array}$} & \multicolumn{2}{|c|}{$95 \% \mathrm{CI}$} & \multirow[t]{2}{*}{$p$ - value } \\
\hline & & & & Upper & Lower & \\
\hline Self-distraction & 1 & 1.554 & 0.157 & -0.142 & 1.174 & 0.123 \\
\hline Active coping & 1 & -0.696 & -0.073 & -1.026 & $0 . .493$ & 0.488 \\
\hline Denial & 1 & 1.117 & 0.115 & -0.308 & 1.103 & 0.266 \\
\hline Substance use & 1 & -0.517 & -0.054 & -0.871 & 0.511 & 0.606 \\
\hline Use of emotional support & 1 & -0.781 & -0.094 & -1.136 & 0.494 & 0.436 \\
\hline Use of instrumental support & 1 & -1.442 & -0.164 & -1.186 & 0.187 & 0.152 \\
\hline Behavioural disengagement & 1 & 2.323 & 0.262 & 0.117 & 1.483 & $0.022 *$ \\
\hline Venting & 1 & -0.784 & -0.081 & -1.022 & 0.443 & 0.435 \\
\hline Positive reframing & 1 & 0.106 & 0.012 & -0.742 & 0.826 & 0.916 \\
\hline Planning & 1 & 0.511 & 0.061 & -0.610 & 1.034 & 0.611 \\
\hline Humour & 1 & -1.484 & -0.161 & -1.080 & 0.155 & 0.141 \\
\hline Acceptance & 1 & -1.125 & -0.125 & -1.232 & 0.340 & 0.263 \\
\hline Religion & 1 & -0.287 & -0.035 & -0.896 & 0.669 & 0.774 \\
\hline Self-blame & 1 & 1.736 & 0.181 & -0.091 & 1.371 & 0.086 \\
\hline
\end{tabular}

\section{Discussion of findings}

The major finding of this study is that denial, behavioural disengagement and self-blame all positively correlate with a higher stress score using the PSS. Meanwhile seeing a student who practices behavioural disengagement can predict a very high stress level among other coping mechanisms used by the students. These finding are in agreement with findings by Abasimi $e t$ al, 2015 in a Ghanaian population, Yamashita et al, 2012, Kaneko \& Momino, 2015 in a Japanese population, and Kirkland, 1998 in a female African American population. The use of emotional support, use of instrumental support, and acceptance all had significant negative correlation with the overall stress level of the respondents. Ab Latif \& Mat Nor, 2016 showed the beneficial effects of acceptance as an effective coping mechanism among undergraduate nursing students. Students who have accepted the reality of the peculiarity of nursing education 
and are learning to live with it are less likely to be as stressed as their counterparts who still live in denial.

Stress management in the male gender is better than in the females, this has been documented in times past (Benavente \& Costa, 2011). Generally speaking, male students in the health sciences feel less stressed compared to their female counterparts (Backović et al, 2012). Our study shows this gender difference in the stress level of the students. The lower stress level of the male students could also be attributable to the fact that the make gender is always exposed to more stress in this part of the world. Right from childhood, the boy-child is made responsible over his siblings; he plays more rough games with his peers and is even punished harder when he errs. All this background might make him less prone to the stress peculiar to nursing education. The male students approach stress differently from the female students (Sulaiman $e t$ al, 2009; Pourrajab et al, 2014).

In this study, unexpected happenings is a major stress contributor among other factors, about half of the respondents sometimes feel upset as a result of something that happened unexpectedly. This can be compared to a study in India where $56.7 \%$ of the nursing students also sometimes feel upset for the same reason (Nancy, 2011). Using the PSS, the she discovered that the inability of the students to control the things happening to them is the single most important factor contributing to their overall stress level. Also, in Saudi Arabia, unexpected happenings contributed significantly to stress (Eswi et al, 2013).

In a more recent Kano study using the PSS conducted by Asani $e t$ al, the overall stress score of the nursing students are higher in all domains when compared with the results from this study (Asani et al, 2016). The study also demonstrated the gender difference in the stress level of the respondents. The overall stress level in our respondents is also much lower that reported by Samson-Akpan et al, 2015 in Calabar and by Omigbodun et al, 2004 in Ibadan, Nigeria.

\section{Summary, limitations, conclusions, and recommendations}

\section{Summary}

This study examined the various stressors and coping strategies of nursing students attending the Osun state school of nursing, Osogbo, Osun state. It has examined the stress level of the students and the relationship between the sociodemographic characteristics of the students and their stress level, showing the association between various coping strategies and the overall stress score and their predictors. This was done using a pretested 2 paged questionnaires. The questionnaire had three sections: 1 . the sociodemographic data, 2. the perceived stress scale (PSS), and 3. The brief coping orientation for problem experiences (COPE). One hundred and twenty nurses were interviewed and their responses were recorded and analysed. Categorical variables were described using frequencies and percentages, while the continuous variables were described using measures of central tendencies and measures of dispersion (Mean, median, standard deviation and range) as appropriate. Differences between means was determined using analysis of variance (ANOVA) and a $\mathrm{P}$ value of $<0.05$ was considered statistically significant. Pearson's Coefficient of Correlation for quantitative variables was used to determine association between the various coping strategies and the overall stress score. Regression analysis made done using cumulative odds ordinal logistic regression with proportional odds. The results show that the level of stress in the students is lower when compared with other studies. The female students have a significant higher stress level as compared with their male counterparts and denial, behavioural disengagement and self-blame correlate positively with a higher stress score. On multiple regression analysis, the odds of respondents who practice behavioural disengagement to be highly stressed is 0.262 (95\% CI, $0.117-1.483$ ) times that of respondents who practice other coping mechanisms.

\section{Limitations}

The researcher was limited by the number of student nurses that were available in the nursing school. Also, the researcher could have made it a multi-centre study but the researcher was 
restrained by financial constraints as there was no funding from any source to finance the study. This put all the financial burden of the research on the researcher.

\section{Conclusion}

The level of stress in the population studied is relatively low when compared with the results from other studies both locally and internationally. The various stressors identified are basically as a result of lack of control over academic events, nervousness, and inability to handle personal problems, irritations, and anger. The stress level in the females is significantly more than in the males and the proportion of stressed females is also significantly higher.

The students are already employing some coping mechanisms to combat their stress experience and students who are practicing behavioural disengagement are highly stressed. Deliberately seeking out these students for proper counselling could help prevent unpleasant life events later in the course of their study. The nursing education authority should look into these stressors with the view to find ways of mitigating them, thereby providing an optimum learning environment for the students. Some of the students already practice other active and avoidant coping techniques.

\section{Recommendation}

A multi-centre study with larger sample size and covering larger population could be beneficial to really get the outlook of other nursing students on a larger scale. This study will be designed to include both public and private nursing schools and also nursing students in the universities. It could be a regional planned study covering the whole of south-western, Nigeria. The benefits of a fully motivating and distress- free nursing education cannot be overemphasized.

\section{References}

[1].Ab Latif, R., \& Mat nor, M. Z. (2016). Stressors and coping strategies during clinical practices among diploma nursing students. Education in Medicine Journal. 8(3):21-33. http://dx.doi.org/10.5959/eimj.v8i3.422.

[2].Abasimi, E., Atindanbila, S., Gai, X., \& Mahamah, M. M., (2015). Analysis of Stress Coping Strategies among Diploma Nursing Students in Ghana. International Journal of Applied Psychology. 2015; 5(2): 26-32. doi: 10.5923/j.ijap.20150502.02.

[3].Ajibade B.L, Olabisi O.O, Fabiyi B, Ajao O.O, \& Ayeni A. (2016). Stress, types of stressors and coping strategies amongst selected nursing schools' students in south-west, Nigeria. European Journal of Biology and Medical Science Research. 4(3): 1-15.

[4].Al-Kandari, F., \& Vidal, V. (2007) Correlation of the health-promoting lifestyle, enrolment level, and academic performance of College of Nursing students in Kuwait. Nurs Health Sci. 9(2):112e9.

[5].Asani, M. O., Farouk, Z., \& Gambo, S., (2016). Prevalence of perceived stress among clinical students of Bayero University Medical School. Niger J Basic Clin Sci, 13: 55-58.

[6].Aston, L., \& Molassiotis, A. (2011). Supervising and supporting student nurses in clinical placements: the peer support initiative. Nurse Educ Today. 23(3):202-210.

[7].Backović, D. V., Živojinović, J. I., Maksimović, J., Maksimović, M. (2012). Gender Differences in Academic Stress and Burnout among Medical Students in Final years of education. Psychiatria Danubina, 24(2): 175-181.

[8].Bankert, E., \& Kozel, V. (2005) Transforming pedagogy in nursing education: a caring learning environment for adult students. Nurs Educ Pers. 26(4):227-229.

[9].Benavente, S. B. T., \& Costa, A. L. S. (2011). Physiological and emotional responses to stress in nursing students: an integrative review of scientific literature. Acta paul. enferm. 24(4). http://dx.doi.org/10.1590/S0103-21002011000400019.

[10]. Brown, H., \& Edelmann, R. P. (2000) A study of expected and experienced stressors and support reported by students and qualified nurses. J Adv Nurs 31(4):857e64. 
DOI: $10.21522 /$ TIJNR.2015.03.02.Art005

ISSN: $2520-3126$

[11]. Burnard, P., Edwards, D., Kim, B., Thaibah, H., Tothova, V., \& Baldacchino, D. (2008) A comparative, longitudinal study of stress in student nurses in five countries: Albania, Brunei, the Czech Republic, Malta and Wales. Nurse Educ Today, 28(2):134e45.

[12]. Chang, E. M., Hancock, K. M., Johnston, A., Daly, J., \& Jackson, D. Role stress in nurses: review of related factors and strategies for moving forward. Nurs Health Sci. 7(1):57e65.

[13]. Deary, I., Watson, R., \& Hogston, R. (2003). A longitudinal cohort study of burnout and attrition in nursing students. J Adv Nurs, 43(1):71e81.

[14]. Del Prato, D., Bankert, E., Grust, P., \& Joseph, J. (2011). Transforming nursing education: a review of stressors and strategies that support students' professional socialization. Advances in Medical Education and Practice. 2: 109-116.

[15]. Eswi, A. S., Radi, S., \& Youssri, H. (2013). Stress/ stressors as perceived by baccalaureate Saudi nursing students. Middle East Journal of Scientific Research. 14(2):193-202.

[16]. Frankel, A. (2009). Nurses' learning styles: promoting better integration of theory into practice. Nurs Times. 105(2):24-27.

[17]. Gibbons, C. (2010). Stress, coping and burn-out in nursing students. International Journal of Nursing Studies, 47, 1299-1309.

[18]. Gibbons, C., Dempster, M., \& Moutray, M. (2007). Stress and eustress in nursing students. Journal of Advanced Nursing, 61(3): 282-290.

[19]. Hughes, L. (1992) Faculty-student interactions and the student-perceived climate for caring. Adv Nur Sci; 14(3):60-71.

[20]. Kaneko S, \& Momino, K. (2015) Stress Factors and Coping Behaviors in Nursing Students during Fundamental Clinical Training in Japan. Int J Nurs Clin Pract 2: 138.

[21]. Khater, W. A. Akhu-Zaheya, L. M. Shaban, I. A. (2014) Sources of Stress and Coping Behaviors in Clinical Practice among Baccalaureate Nursing Students International Journal of Humanities and Social Science. 6(4).

[22]. Kirkland, M. L. (1998). Stressors and coping strategies among successful female African American baccalaureate nursing students. J Nurs Educ. 37(1): 5-12.

[23]. Kohler, J. M., Munz, D. C., \& Grawitch, M. J. (2006). Test of a dynamic stress model for organizational change: do males and females require different models? Appl Psychol Int Rev, 55(2):168e91.

[24]. Lazarus R, Folkman S. Stress, appraisal, and coping. New York, NY: Springer, 1984.

[25]. Leodoro, J. L. (2013). Stress, stressors, and stress responses of student nurses in a government nursing school. Health Science Journal. 7(4): 424-435.

[26]. Lim, J., Bogossian, F., \& Ahern, K., (2010) Stress and coping in Australian nurses: a systematic review. Int Nurs Rev, 57: 22e31.

[27]. Lindop, E. (1999). A comparative study of stress between pre- and post-Project 2000 students. J Adv Nurs, 29(4):967e73.

[28]. MacArthur (2014) Coping strategies. Retrieved from http//: www.macses.ucsf.eduon 26/04/2017.

[29]. Nancy, R. K., (2011). Stress and Coping Strategies among Nursing Students. Nursing and Midwifery Research Journal, 7(4).

[30]. Omigbodun, O. O., Onibokun, A. C., Yusuf, B. O., Odukogbe, A. A., \& Omigbodun, A. O. (2004). Stressors and Counselling Needs of Undergraduate Nursing Students in Ibadan, Nigeria. Journal of Nursing Education. 43(9): 412-415.

[31]. Papastavrous, E., Lambrinou, L., Tsangan, H., Saarikoski, M., \& Leino-Kilpi, H. (2010) Student nurses experience of learning in the clinical environment. Nurs Educ Practice. 10(3):176-182.

[32]. Papp, I., Markkanen, M., \& von Bonsdorff, M. (2003) Clinical environment as a learning environment: student nurses' perceptions concerning clinical learning experiences. Nurs Educ Today, 23(4):262-268.

[33]. Pourrajab, M., Rabbani, M., \& Kasmaienezhadfard, S. (2014). Different effects of stress on male and female students. The Online journal of Counselling and Education, 3(3): 31-39.

[34]. Pryjmachuk, S., \& Richards, D. A. (2007) Mental health nursing students differ from other nursing students: some observations from a study on stress and coping. Int J Ment Health Nurs, 16(6):390e402. 
[35]. Pulido-Martos, M., Augusto-Landa, J. M., Lopez-Zafra, E. (2011) Sources of stress in nursing students: a systematic review of quantitative studies. Int Nurs Rev, 59(1):15e25.

[36]. Samson-Akpan, P. E., John, M. E., Edet, O. B., Ella, R. E. (2015). Stress and Coping Strategies among Undergraduate Nursing Students in University of Calabar, Nigeria. Scientific Poster Session 2 at the 43rd Biennial convention of Sigma Theta Tau International, Las Vegas, Nevada, USA.

[37]. Seyedfatemi, N., Tafreshi, M., \& Hagani, H. (2007). Experienced stressors and coping strategies among Iranian nursing students. Biomedical Nursing, 6 (11): 1-10.

[38]. Sharma, N., Kaur, A. (2011) Factors associated with stress among nursing students. Nursing and Midwifery Research Journal, 7(1): 12-21.

[39]. Sheu, S., Lin, H-S., \& Hwang, S. L. (2002). Perceived stress and physio-psycho-social status of nursing students during their initial period of clinical practice: the effect of coping behaviours. International Journal of Nursing Studies, 39, 165-175.

[40]. Sulaiman, T., Hassan, A., Sapian, V. M., \& Abdullah, S. K. (2009). The Level of Stress among Students in Urban and Rural Secondary Schools in Malaysia. European Journal of Social Sciences, 10(2): 179-184.

[41]. Watson, R., Deary, I., Thompson, D., \& Li, G. (2008). A study of stress and burnout in nursing students in Hong Kong: A questionnaire survey. International Journal of Nursing Studies, 45 (10): 15341542.

[42]. Yamashita, K., Saito, M., Toshihiro, T. T. (2012). Stress and coping styles in Japanese nursing students. International Journal of Nursing Practice. 18(5): 489-496. http://dx.doi.org/10.1111/j.1440172X.2012.02056.x. 